\begin{tabular}{|l|l|r|}
\hline Al Fitrah & $\begin{array}{r}\text { Pengelolaan Sumber Belajar dalam } \\
\text { Meningkatkan Pemahaman Peserta } \\
\text { didik } \\
\text { Journal Of Early Childhood Islamic Education } \\
\text { ISSN : 2599-2287 E-ISSN : 2622-335X }\end{array}$ \\
Vol.2 No.1 Juli 2018 & Suhirman \\
\hline
\end{tabular}

\title{
PENGELOLAAN SUMBER BELAJAR DALAM MENINGKATKAN PEMAHAMAN PESERTA DIDIK
}

\begin{abstract}
Abstrak
Sumber belajar yang dapat di pergunakan dalam meningkatkan pemahaman peserta didik, berupa:pesan, manusia, material, peralatan, teknik, lingkungan, bahan, perstiwa untuk memfasilitasi proses pembelajaran dan dapat memberi masukan, informasi, pengertian serta kemudahan kepada peserta didik. Sumber belajar dapat memerikan pengalaman baru yang lebih kongkret dan langsung dalam menjelaskan halhal yang tidak mungkin diadakan, dan memperluas wawasan sehingga peserta didik dapat berfikir kritis dan positif serta dapat memberikan informasi yang akurat dan terbaru sehingga peserta didik termotivasi untuk belajar dengan menyenangkan. Sumber belajar dapat mengembangkan berbagai potensi yang beragam dan bervariasi, seperti: kemampuan, sikap dan minat yang sesuai dengan karakteristik dan kebutuhannya.
\end{abstract}

Suhirman

suhirman@gmail.com

Kata kunci: Sumber belajar, pemahaman dan peserta didik

\section{Pendahuluan}

Sumber belajar merupakan sumber pengetahuan yang memilikiberbagai dimensi, yaitu sumber belajar di tinjau dalam artian yang sempit hingga pada pengertian yang luas. Sumber belajar dalam artian yang sempit yaitu sumber belajar yang tercakup pada buku-buku atau bahanbahan tercetak, seperti majalah, bulletin dan sebagainya, dan dalam artian yang luas sumber belajar berupa sarana pembelajaran yang dapat menyajikan pesan dan dapat di dengar maupun yang dapat di lihat, seperti: radio, televise dan perangkat keras.

Eksistensi sumber belajar sangat penting dalam proses belajar pembelajaran, sebab tanpa adanya sumber belajar dalam proses pembelajaran tidak akan terjadi. Association for Educational Communication and Technology atau Asosiasi Komunikasi dan Teknologi Pendidikan yang sering disingkat $\mathrm{AECT}^{1}$ (dalam Miarso) memberikan batasan sumber belajar merupakan segala sesuatu yang berupa pesan, manusia, bahan (software), peralatan (hardware), teknik (method), dan lingkungan yang digunakan secara sendiri-sendiri maupun dikombinasikan untuk memfasilitasi terjadinya kegiatan pembelajaran.

1 Yusufhadi Miarso, Menyemai benih teknologi pendidikan (Jakarta: Kencana, 2004), h. 328. 


\begin{tabular}{|l|l|r|}
\hline & Al Fitrah & Pengelolaan Sumber Belajar dalam \\
Journal Of Early Childhood Islamic Education & Meningkatkan Pemahaman Peserta \\
didik \\
ISSN : 2599-2287 E-ISSN : 2622-335X \\
Vol.2 No.1 Juli 2018
\end{tabular}

Pengertian sumber belajar menurut AECT di atas menjelaskan jenis-jenis sumber belajar yang dapat digunakan dalam kegiatan pembelajaran meliputi pesan, orang, bahan, peralatan, teknik, dan lingkungan sekitar. Banyaknya sumber belajar dan alat digunakan dalam proses pembelajaran mensyaratkan guru untuk mengelolanya secara efektif dan efisien. Dengan demikian pentingnya pengelolaan sumber belajar dan pemanfaatannya untuk memfasilitasi proses belajar peserta didik dalam mengembangkan potensi yang dimilikinya.

Sumber belajar dalam hal ini dapat meliputi berupa alat, bahan, peralatan, pengaturan dan orang-orang yang berinteraksi dengan peserta didik untuk memfasilitasi pembelajaran dan meningkatkan pemahaman peserta didik dalam pembelajaran. Sumber belajarpembelajaran dan bagaimana sumber daya ini digunakan untuk melayani dan untuk membedakan apa yang dilakukan oleh teknolog pendidikan dari upaya-upaya peningkatan pembelajaran yang serupa di bidang lain.

Dalam konteks definisi saat ini, istilah teknologi, sebagai pengubah sumber daya menunjukkan bahwa sumber daya yang dibuat dan digunakan dalam teknologi pendidikan yang paling sering adalah berupa alat, bahan, perangkat, dan orangorang. sumber daya lainnya, seperti sumber daya alam atau sumber daya politik tidak dianggap begitu penting terutama dalam teknologi pendidikan dan karenanya tidak begitu terpusat pada bidang lain di luar pendidikan. Sementara profesional teknologi pendidikan adalah pembelajaran dari guru yang benar-benar dapat memahami dan menerapkan ilmudari bidang lainnya, seperti dari sumber daya non-teknologi, termasuk sumber daya teknologi pendidikan yang menyediakan fokus pada alat, bahan, perangkat, pengaturan, dan orang-orang sebagai sumber daya utama yang digunakan untuk meningkatkan belajar dan kinerja pembelajaran. Hal ini dapat disimpulkan bahwa, sementara tren saat ini memang mengarah ke peningkatan penggunaan sumber daya digital, serta para instruktur akan terus menggunakan dan permintaan dukungan untuk sejumlah media audiovisual tradisional (AV).

Istilah yang sesuai digunakan untuk memodifikasi sumber daya untuk menunjukkan bahwa perangkat keras dan perangkat lunak yang digunakan dalam pendidikan harus dipilih dengan mempertimbangkan kesesuaian dan kompatibilitas dengan tujuan pendidikan. Hal ini tidak selalu merupakan persyaratan 


\begin{tabular}{|l|l|r|}
\hline A1 Fitrah & $\begin{array}{r}\text { Pengelolaan Sumber Belajar dalam } \\
\text { Journal Of Early Childhood Islamic Education }\end{array}$ \\
ISSN : 2599-2287 E-ISSN : 2622-335X & Meningkatkan Pemahaman Peserta \\
didik \\
Vol.2 No.1 Juli 2018
\end{tabular}

mudah untuk di penuhi. Media pustakawan, koordinator teknologi, dan desainer instruksional sering menghadapi tantangan di wilayah ini, misalnya:

1) Untuk memiliki akses siap bahan ajar yang dibutuhkan, seorang guru ingin menduplikasi video di luar batas-batas penggunaan yang di izinkan dalam pembelajaran.

2) Untuk memungkinkan semua siswa di distrik sekolah baik kaya ataupun miskin untuk menggunakan aplikasi komputer saat ini, seorang pengawas sekolah ingin menggunakan perangkat lunak berlisensi guna kelancaran administrasi dalam pendidikan.

3) Untuk menyampaikan ide-ide penting dalam program pendidikan jarak jauh seorang profesor ingin menggabungkan beberapa visual download dari sebuah situs web tanpa bertanya tentang izin.

\section{Lingkungan Sebagai Sumber Belajar}

Sumber belajar merupakan bagian yang takterpisahkan lagi dengan kegiatan belajar peserta didik dan sangat membantu dalam aspek perkembangannya, baik aspek kognitif, sosial, bahasa, motorik, afeksi, moral dan sebagainya yang merupakan suatu sistem proses pembelajaran. Sistem ini adalah sekumpulan komponen dimana antara satu komponen dengan komponen yang lain saling berhubungan, saling ketergantungan dalam rangka mencapai tujuan.

Demikian pula halnya dalam konsep pembelajaran di sekolah sebagai suatu sistem yang didalamnya terdiri dari beberapa komponen atau unsur. Keseluruhan aspek atau unsur tersebut pada hakekatnya saling berkaitan, saling berhubungan dalam rangka mencapai tujuan. Komponen atau unsur yang terdapat dalam system pembelajaran anak tersebut terdiri dari peserta didik sebagai masukan atau input proses pembelajaran dan hasil belajar peserta didik sebagai keluaran atau output.

Sumber belajar sebagai salah satu komponen atau unsur pembelajaran di kelas memegang peranan penting dalam rangka terselenggaranya kegiatan pembelajaran yang menarik dan bermakna.

Dengan tersedianya sumber belajar memungkinkan tumbuhnya budaya belajar peserta didik secara mandiri sebagai dasar untuk pembiasaan dalam kehidupan di kemudian hari serta menciptakan komunikasi antara anak dengan orang dewasa dan teman sebaya. Namun penyajian sumber belajar untuk peserta didik harus nyata dan sederhana agar dapat membantu pengembangan kemampuan berfikir peserta didik dan sesuai dengan 


\begin{tabular}{|l|l|r|}
\hline & Al Fitrah & Pengelolaan Sumber Belajar dalam \\
Journal Of Early Childhood Islamic Education & Meningkatkan Pemahaman Peserta \\
didik \\
ISSN : 2599-2287 E-ISSN : 2622-335X \\
Vol.2 No.1 Juli 2018
\end{tabular}

taraf kemampuannya. Berikut ini ada beberapa pertimbangan mengenai pentingnya sumber belajar dalam pembelajaran: sumber belajar memberi kesempatan untuk mendapatkan pengetahuan dan memperkaya peserta didik dengan menggunakan berbagai pilihan sumber belajar seperti buku, alat, narasumber, metode, lingkungan yang semuanya dapat menambah pengetahuan.

Dalam hal ini sumber belajar memfasilitasi peserta didik untuk menyalurkan keingintahuannya yang kuat dan antusias terhadap banyak hal, sumber belajar dapat meningkatkan kemampuan peserta didik dalam berbahasa, caranya dengan berbicara dan berkomunikasi dengan narasumberatau guru yang dapat mengembangkan pandangan peserta didik dalam berbagai aspek kehidupan, sumber belajar dapat membantu mengenalkan anak pada lingkungan dan juga mengajar peserta didik mengenal kekuatan maupun kelemahan dirinya. Hal ini bias menggunakan alat permainan sebagai sumber belajar sehingga dapat memotivasi anak untuk melakukan kegiatan yang jelas dan menggunakan panca indranya secara aktif, contoh, kepingan puzzle, sumber belajar dapat menumbuhkan motivasi belajar anak sehingga perhatian anak meningkat. Sumber belajar yang beragam dan bervariasi akan menimbulkan rasa keterkaitan anak terhadap bahan ajar yang akan diberikan. Peserta didik bias memilih sumber belajar mana yang paling cocok dan sesuai dengan minatnya masing-masing hal ini akan membuat suasana pembelajaran terasa lebih dinamis mengingat siswa semangat untuk belajar, sumber belajar memungkinkan anak untuk mencapai tujuan pembelajaran dengan lebih baik dan sumber belajar mendukung peserta didik untuk lebih banyak melakukan kegiatan belajar yaitu selain mendengarkan uraian dari guru tetapi juga mengamati, melakukan, mendemontrasikan dan lain-lain.

Lingkungan merupakan kesatuan ruang dengan semua benda dan keadaan makhluk hidup termasuk di dalamnya manusia dan perilakunya serta makhluk hidup lainnya. Lingkungan adalah segala sesuatu yang ada di sekitar. Lingkungan terdiri dari unsur-unsur biotik dan abiotic dan budaya manusia. Lingkungan sebagai sumber belajar dapat diartikan segala sesuatu yang ada di sekitar peserta didik yang dapat dimanfaatkan untuk menunjang kegiatan belajar dan pembelajaran secara lebih optimal.

Pemanfaatan lingkungan sebagai sumber belajar mengarahkan peserta didik pada peristiwa dan keadaan yang sebenarnya, keadaan alami sehingga lebih 


\begin{tabular}{|l|l|r|}
\hline A1 Fitrah & Pengelolaan Sumber Belajar dalam \\
\hline Journal Of Early Childhood Islamic Education & Meningkatkan Pemahaman Peserta \\
didik \\
ISSN : 2599-2287 E-ISSN : 2622-335X \\
Vol.2 No.1 Juli 2018
\end{tabular}

nyata, lebih actual dan kebenarannya lebih dipertanggungjawabkan, manfaat nyata yang dapat diperoleh dengan penggunaan lingkungan diantaranya adalah menjadikan berbagai hal yang dapat dipelajari oleh peserta didik, memingkinkan terjadinya proses belajar yang lebih bermakna, memungkinkan terjadinya proses pembentukan kepribadian peserta didik, kegiatan belajarakan lebih menarik dan menumbuhkan aktivitas belajar peserta didik. Jenis lingkungan yang dapat dimanfaatkan untuk mengoptimalkan kegiatan pembelajaran di kelas, terdiri atas lingkungan fisik dan lingkungan sosial. Lingkungan fisik adalah segala sesuatu yang alamiah dan sifatnya realtif menetap, seperti air, tanah, batu-bantuan, tumbuhan, hewan, sungai, iklim, suhu udara. Lingkungan social berkenaan dengan interaksi anak dalam kehidupan bermasyarakat serta dapat digunakan untuk mempelajari ilmu-ilmu social dan kemanusiaan.

\section{Pemanfaatan Sumber Belajar}

Beberapa sumber belajar yang dapat digunakan untuk mempermudah pembelajaran karena secara khusus dirancang untuk tujuan belajar. Ini biasanya disebut "bahan ajar atau sumber belajar". sumber belajar lainnya yang ada sebagai bagian dari dunia kehidupan normal seharihari, namun dapat ditemukan, diterapkan, dan digunakan untuk tujuan pembelajaran. Ini kadang-kadang disebut "sumber belajar dunia nyata" Jadi, beberapa sumber menjadi sumber belajar dengan desain dan lainnya menjadi sumber belajar melalui pemanfaatan. Hal ini penting karena menjelaskan posisi pembelajaran, sumber belajar yang nyata serta sumber belajar yang dirancang sebagai bidang perhatian untuk teknologi pendidikan.

Teknologi sumber belajar dan pembentukan identitas awal,ditandai oleh organisasi guru, buku teks, papan tulis, dan mahasiswa. Pada awal pendidikan biasanya dianggap telah mendahului bidang teknologi pendidikan dan sering disebut sebagai pendidikan tradisional ${ }^{2}$. Penggunaan ilustrasi tangan yang dituangkan dalam buku teks merupakan salah satu contoh tertua penggunaan sumber belajar pendidikan dan dianggap oleh beberapa orang untuk menandai awal atau asal-usul bidang teknologi pendidikan.

Gerakan di atas ditandai dengan munculnya penggunaan gambar diam dan teknologi film sebagai sumber belajar. Upaya awal untuk membuat sumber belajar ini secara luas tersedia di seluruh distrik

${ }^{2}$ Rusli, Teknologi Komunikasi dan Informasi dalam Pendidikan: Kurikulum untuk Sekolah dan Program Pengembangan Guru (Jakarta: Gaung Persada, 2009), h. 1. 


\begin{tabular}{|l|l|r|}
\hline & Al Fitrah & Pengelolaan Sumber Belajar dalam \\
Journal Of Early Childhood Islamic Education & Meningkatkan Pemahaman Peserta \\
didik \\
ISSN : 2599-2287 E-ISSN : 2622-335X \\
Vol.2 No.1 Juli 2018
\end{tabular}

sekolah termasuk pengumpulan dan organisasi bahan visual ke museum pendidikan. film bisu (tanpa suara) mulai digunakan di sekolah-sekolah pertama kali pada awal tahun 1910 (Seattler, 1990, hlm 98-99), 1910-an dan 1920 adalah waktu fermentasi yang cukup lama dalam penggunaan film untuk pendidikan. Banyak individu yang berbeda, perusahaan, organisasi nirlaba, dan lembaga pemerintah berusaha untuk menambah pasokan yang sudah ada dari filmberita teoritis dan gulungan.

Sekolah dengan citra progresif tentang pendidikan ingin dipandang sebagai salah satu institusi yang berkaitan dengan teknologi baru dan bergegas untuk mendirikan katalog koleksi film untuk pembelajaran. Sayangnya, banyak film-film yang tersedia adalah nilai pendidikan marjinal dan guru sering memilih untuk menunjukkan film untuk alasan lain selain relevansi kurikuler mereka. Namun demikian, penggunaan film untuk pendidikan terus tumbuh sepanjang tahun 1910-an dan 1920-an. Pada akhir dekade ini, lebih dari setengah lembaga negara pendidikan telah di buat unit khusus untuk film atau pendidikan visual dan katalog yang tebal dalam proses mendokumentasikan ribuan film yang tersedia untuk pendidik.

\section{a. Audiovisual.}

Beberapa sumber belajar audiovisual adalah:

1) Rekaman: piringan hitam, mulai di gunakan pada tahun 1910, merupakan format pertama yang tersedia secara luas untuk rekaman suara, digunakan hampir secara eksklusif untuk musik.

2) Film bersuara: Beberapa metodologi menjelaskan bahwa praktik mengajar memiliki guru kelas untuk menambahkan narasi film bisu menambahkan tingkat kustomisasi dan personalisasi untuk pemutaran film.

3) Radio: Sementara itu, sumber-sumber radio lain berkembang di awal 1920-an, banyak universitas Amerika memperoleh stasiun radio berlisensi untuk mengoperasikan stasiun radio, sering sebagai percobaan teknis di bidang teknik listrik dan topik lain dalam perkuliahan yang berhubungan dengan radio.

4) Audiovisual media: The audiovisual media yang telah diperkenalkan sejak akhir 1930-an adalah proyektor slide lentera, filmstrip proyektor, proyektor tembus cahaya, proyektor $35 \mathrm{~mm}$ film bisu, penerima radio, slide proyektor mikro, proyektor film $16 \mathrm{~mm}$ suara.

5) Davi: Davi adalah Departemen Audiovisual Instruksi merupakan alat 


\begin{tabular}{|l||l|r|}
\hline Al Fitrah & $\begin{array}{r}\text { Pengelolaan Sumber Belajar dalam } \\
\text { Meningkatkan Pemahaman Peserta } \\
\text { didik }\end{array}$ \\
\hline Journal Of Early Childhood Islamic Education & Suhirman \\
\hline ISSN : 2599-2287 E-ISSN : 2622-335X & \\
Vol.2 No.1 Juli 2018 & \\
\hline
\end{tabular}

yang sama pada media audiovisual dan digunakan untuk memberikan bahan pelajaran pada akhir tahun 1947 di Amerika.

\section{b. Teknologi Pendidikan dan}

\section{Komunikasi}

Sejak tahun 1950-an, mulainya televisi digunakan sebagai program pendidikan. Banyak pihak yang sama yang telah bereksperimen dengan radio juga melakukannya dengan televisi, pada dasarnya mengulang skenario yang ada pada radio. Seperti memiliki lisensi radio sebelumnya, pemegang lisensi televisi berjanji bahwa televisi akan memungkinkan untuk sekolah umum yang miskin dan paling terpencil untuk menikmati keuntungan dari metode pengajaran yang paling modern.

Modus perubahan dan sistem pengiriman yang ditimbulkan oleh revolusi komputer memiliki dampak yang mendalam terhadap kehidupan profesional yang terkait dengan teknologi pendidikan. Dalam kasus AECT, hal itu telah mengubah dialog dalam asosiasi dengan mayoritas pemain publikasi dan sesi referensi yang ditujukan untuk pertimbangan komputasi pembelajaran. Danhal tersebut telah membawa asosiasi lain pada masyarakat internasional untuk dalam hal teknologi dalam pendidikan yang menarik dalam hal ini terutama untuk guru yang memainkan peran utama dalam menggunakan komputer di sekolah mereka. Dalam banyak kasus, koordinator teknologi sekolah, harus telah menguasai spesialis AV atau sekolah spesialis media sebagai wakil yang paling di butuhkandari teknologi untuk pembelajaran yang terus berkembang.

Seperti pada bidang lain yang telah berkembang, beberapa orang dan organisasi-terutama di bidang yang terkait dengan pendidikan yang juga peduli dengan penggunaaan sumber daya untuk pengajaran dan pelatihan yang terus mempertahankan fokus sempit pada sumber daya sebagai perangkat keras yang didorong daripada teori atau proses, karena mereka telah menggariskan dan menetapkan konsepsi mereka sendiri dalam teknologi pendidikan. Pemeliharaan fokus yang sempit pada alat teknologi pendidikan dan bukan pada sistem pendidikan yang lebih luas dan lebih canggih di mana mereka ada dan dapat menyebabkan salah membaca pengaruh potensial yang dapat memiliki alat teknologi pendidikan. Misalnya, ada futuris pendidikan yang telah banyak (hal ini sering tidak terpikir oleh pendidik sendiri) yang memiliki dampak potensial yang sangat berlebihan dari teknologis yang muncul tentang pendidikan. 


\begin{tabular}{|l|l|r|}
\hline & Al Fitrah & Pengelolaan Sumber Belajar dalam \\
Journal Of Early Childhood Islamic Education & Meningkatkan Pemahaman Peserta \\
didik \\
ISSN : 2599-2287 E-ISSN : 2622-335X \\
Vol.2 No.1 Juli 2018
\end{tabular}

c. Alat, bahan, dan perangkat sebagai sumber belajar

Dalam teknologi pendidikan, istilah ini secara historis digunakan untuk memilih sistem pengiriman melalui pesan yang disampaikan dengan cara penggunaan yang berupacetakan, proyeksi gambar, televisi, radio, film suara dan sejenisnya. Atau bisa dilihat dari bahan ajar sendiri yang berupa overhead transparansi, slide, filmstrips, audio-kaset, dan sejenisnya. Saat ini istilah ini paling sering digunakan untuk mengacu pada perangkat fisik yang menyimpan data (contoh: floppy disk, flash drive, CD, kaset video, atau DVD ROM) sehingga cenderung menjadi cakupan semuanya yang bisa merujuk kepada sebuah alat dan bahan/perangkat ${ }^{3}$, seperti:

1) Alat Analog, bahan dan perangkat.

Dalam penggunaan sehari-hari, analog hanya berarti sesuatu yang menyerupai sesuatu yang lain. Oleh karena itu, analog adalah obyek atau ide yang digunakan sebagai titik acuan untuk menjelaskan beberapa data lainnya. Istilah ini memiliki arti yang lebih teknis di bidang teknik di mana sebuah sinyal analog merupakan salah satu variabel yang terus menerus baik

${ }^{3}$ Deni, Darmawan, Pendidikan Teknologi Informasi dan Komunikasi, Bandung, PT. Remaja Rosdakarya, 2012, h.249 dalam hal waktu dan amplitudo-sebagai lawan dari sinyal digital, yang dalam keadaan menyala ataupun padam atauyang tidak teruskan dalam tingkat variabel.

Rekaman suara analog dibuat dengan menerjemahkan variasi tekanan udara yang mencolok pada setiap variasi yang ada pada mikrofon di amplitudo tegangan. Yaitu, terlihat fluktuasi tegangan 'seperti "fluktuasi tekanan udara; yang tetap pada seluruh dimensi. gambar televisi analog yang mirip dengan proyeksi film di seluruh gambar dilukis pada layar dengan setiap frame. Jadi audio-kaset dan kaset video adalah media perekaman analog.

2) Alat Digital, bahan dan perangkat.

Media digital adalah media yang menyimpan dan disampaikan melalui kode digital, biasanya kode binero atau 1, nyala atau padam. Tidak seperti media analog, digital representasiserangkaian-nol dan yang tidak memiliki kemiripan dengan foto asli atau suara, yang mungkin awalnya dicatat melalui cara-cara analog. Ada beberapa alat digital yang di gunakan untuk pembelajaran, yaitu:

\section{3) Komputer.}

Kecenderungan masyarakat terhadap peningkatan penggunaan 


\begin{tabular}{|c|c|c|}
\hline & $\begin{array}{l}\text { A1 Fitrah } \\
\text { Journal Of Early Childhood Islamic Education } \\
\text { ISSN : 2599-2287 E-ISSN : 2622-335X } \\
\text { Vol.2 No.1 Juli } 2018\end{array}$ & $\begin{array}{r}\text { Pengelolaan Sumber Belajar dalam } \\
\text { Meningkatkan Pemahaman Peserta } \\
\text { didik } \\
\text { Suhirman }\end{array}$ \\
\hline
\end{tabular}

komputer ini sangat mungkin untuk terus-menerus meningkat ke masa depan, dan sebagai teknologi pendidikan sangat erat kaitannya dengan teknologi, ada kemungkinan bahwa sumber daya pendidikan masa depan akan semakin digital dan berbasis komputer. Saat ini, komputer pribadidaninternet berfungsi sebagai alat utama pendidikan teknologi yang menyimpan, mengorganisir, mengambil, dan berinteraksi dengan sumber daya digital.

\section{4) Internet dan World Wide Web.}

Komputer berbasis World Wide Web browser (contoh; navigator Netscape, Mozilla Firefox, Apple Safari dan Microsoft Internet Explorer) saat ini merupakan alat utama yang digunakan untuk mengakses bahan pembelajaran di internet. Jenis bahan ajar yang tersedia untuk digunakan dengan komputer termasuk perangkat lunak pendidikan, permainan edukatif, simulasi pembelajaran, Edutainment, video instruksional, bahan referensi, rekaman audio, dan film.

\section{5) Interaktif lingkungan.}

Pendidik telah lama menghargai nilai metode yang melibatkan peserta didik dalam pengaturan masalah realistis. Simulasi dan game simulasi memungkinkan pembelajar untuk mengeksplorasi situasi dinamis yang kompleks, seperti konflik antar individu dan kelompokdalam pembelajaran.

6) Pencarian web.

Pada awalnya pendidik melihat web sebagai database besar yang dapat digunakan oleh peserta didik untuk menghasilkan jawaban atas pertanyaan mereka sendiri. Sebagai quests strategi pembelajaran generatif dalam web yang bertujuan untuk belajar melibatkan konstruksi pengetahuan baru melalui suatu proses berpikir kritis.

7) Web berbasis pendidikan jarak jauh.

Bagibeberapa kelompok dalam dunia pendidikan, "pendidikan jarak jauh berbasis web" adalah nama program berbasis web yang khas hanya sebagian dari kegiatan program yang berbasis di layar webyang berbentuk informasi, seperti silabus dan daftar tugas. Peserta didik biasanya berkomunikasi satu sama lain dengan instruktur melalui layanan internet lain, termasuk e-mail, bulletin, chatting, dan file-sharing melalui transfer file (FTP), dan mereka dapat menggunakan buku teks atau bacaan onlineyang dapat digunakan untuk konten presentasi. 


\begin{tabular}{|l|l|r|}
\hline & Al Fitrah & Pengelolaan Sumber Belajar dalam \\
Journal Of Early Childhood Islamic Education & Meningkatkan Pemahaman Peserta \\
didik \\
ISSN : 2599-2287 E-ISSN : 2622-335X \\
Vol.2 No.1 Juli 2018
\end{tabular}

\section{8) Kursus manajemen sistem.}

Perangkat lunak aplikasi yang memberikan dorongan untuk instruksi berbasis web adalah program manajemen sistem (CMS), yang dikembangkan pada akhir tahun 1990an dan mengumpulkan momentum di awal tahun 2000. CMS adalah aplikasi suiteyang merupakan usaha bersama dalam hal layanan yang telah disebutkan sebelumnya, sehingga siswa dapat login sekali dan semua layanan komunikasi yang tersedia di dalam database dapat mereka akses dengan cepat sebagai alat, bahan sekaligus media dalam pembelajaran, tanpa melompat masuk dan keluar dari web.

\section{9) Emerging aplikasi.}

Banyaknya janji pendidikan dalam fungsi baru dan fitur baru internet dan aplikasi web. Weblog (blog) misalnya, memberikan tingkatan yang tinggi dalam interaksi antar pengguna, yang bisa menjadi instruktur dan peserta didik.

10) Mobile Media.

Sebagian besar akses internet dicapai melalui komputer desktop internet, maka hal ini ada kecenderunganuntuk mengakses internet melalui alatkoneksi yang lebih kecil, seperti perangkat portabel yang berupa telepon digital, jam tangan, komputer laptop, komputer kompak, notebook dan personal digital asisten (PDA). Elektronik mendukung kinerja (EPSS). The EPSS biasanya toko organisatoris pengetahuan para ahli khusus untuk karyawan untuk referensi yang diperlukan.

\section{1) Penetapan sumber.}

Pengaturan sumber belajarini terdiri dari sumber daya masyarakat dan sumber daya orang yang akan terbagi menjadi tema yang lebih kecil untuk didiskusikan. Apakah pengaturan di mana belajar dan kinerja terjadi bersifat internal atau eksternal, sederhana atau kompleks, kemampuan untuk mengaturnya tepat atau sangat penting bagi para profesional teknologi pendidikan.

Sumber belajar masyarakat, seperti museum, perpustakaan, kebun binatang, rumah sakit, kantor polisi, dan departemen yang dapat melayani untuk mengekspos pelajar untuk contoh otentik dan ide-ide mereka belajar di ruang kelas. Sumber daya ini dibagi menjadi; bidang perjalanan, perjalanan virtual, dan lingkungan belajar yang kaya informasi. 


\begin{tabular}{|c|c|c|}
\hline & $\begin{array}{l}\text { A1 Fitrah } \\
\text { Journal Of Early Childhood Islamic Education } \\
\text { ISSN : 2599-2287 E-ISSN : 2622-335X } \\
\text { Vol.2 No.1 Juli } 2018\end{array}$ & $\begin{array}{r}\text { Pengelolaan Sumber Belajar dalam } \\
\text { Meningkatkan Pemahaman Peserta } \\
\text { didik } \\
\text { Suhirman }\end{array}$ \\
\hline
\end{tabular}

12) Orang sebagai sumber belajar

Dukungan staf ahli subyek seringkali menjadi sumber belajar untuk instruktur dan peserta didik. Sumber belajar ini terdiri dari spesialis teknologi pendidikan ahli subjek (orang yang ahli dalam bidang pendidikan tertentu).

\section{3) Teknologi pendidikan}

Teknologi pendidikan bertanggung jawab untuk mengatasi pertimbangan etika yang muncul ketika menggunakan dan mengelola sumber belajar. Spesialis teknologi Pendidikan dapat menerapkan di sekolah, di perguruan tinggi dan universitas, atau di perusahaan, pemerintah dan organisasiorganisasi besar lainnya. Para ahli adalah pengetahuan tentang sesuatu yang digunakan selama instruksi sebagai cara untuk memberikan peserta didik akses langsung ke pakar. Hal ini telah digunakan sebagai bagian integral dari menciptakan dan menerapkan pembelajaran lingkungan.

\section{4) Etika dan Sumber Belajar}

Masalah etika dan sumber belajar merupakan aksesibilitas dan alokasi yang adil telah menjadi semakin penting dalam beberapa tahun terakhir.

Sebuah keprihatinan pusat kajian secara profesional berkenaan dengan etika dan sumber belajar adalah upaya untuk menjamin akses yang adil terhadap sumber belajar untuk semua peserta didik. Perkembangan media digital aksesibilitas dan desain secara umum adalah dua bidang desain yang bersinergi.

Sumber Belajar sebagai Alat Permainan Edukatif

Eksistensisumber belajar dalam pengadaannya, terutama pengadaan alat permainan edukatif harus mempertimbangkan tentang pemahaman terhadap seluk-beluk alat-alat permainan edukatif. Tercapai atau tidaknya tujuan belajar pada anak melalui kegiatan bermain ditentukan oleh jenis alat permainan edukatif yang digunakan, sebab tujuan memberikan berbagai permainan pada peserta didik tidak lain adalah memperkenalkan kepada mereka berbagai konsep, seperti: warna, bentuk, perbedaan dan persamaan, panjang dan pendek, berat dan ringan, tenggelam dan terapung, dan lain sebagainya. Oleh karena itu, memerhatikan karakteristik dan seluk-beluk serta fungsi berbagai alat permainan edukatif yang mampu menunjang tercapainya tujuan belajar melalui bermain sangat penting, sehingga harus diperhatikan secara seksama sebelum melakukan 


\begin{tabular}{|l|l|r|}
\hline & Al Fitrah & Pengelolaan Sumber Belajar dalam \\
Journal Of Early Childhood Islamic Education & Meningkatkan Pemahaman Peserta \\
didik \\
ISSN : 2599-2287 E-ISSN : 2622-335X \\
Vol.2 No.1 Juli 2018
\end{tabular}

pengadaan atau pembelian alat permainan edukatif.

Berbagai cara, pendekatan dan kegiatan yang dapat dilakukan untuk mengadakan sumber belajar antara lain: dengan pembelian, hadiah/sumbangan, pembuatan, dan memodifikasi yang sudah ada. Pembelian merupakan suatu kegiatan pengadaan sumber belajar melalui transaksi pembelian. Untuk membeli sejumlah bahan diperlukan tersedianya sejumlah dana. Oleh karena itu ditengah keterbatasan dana, seorang guru dituntut untuk dapat memilih sumber belajar mana saja yang perlu dijadikan prioritas utama.

Pembelian secara bertahap dapat dilakukan sejalan dengan kemampuan anggaran yang tersedia. Prosedur pembelian dapat dilakukan melalui cara pembelian langsung ke toko atau melalui pemesanan ke penyalur atau langsung ke agen/pabrik pembuat sumber belajar tersebut. Sumbangan penambahan koleksi sumber belajar dapat diperoleh dari hadiah, pemberian, hibah ataupun sumbangan dari berbagai pihak seperti instansi pemerintah, swasta ataupun perorangan. Sumbangan atau bantuan yang diterima ada kalanya tanpa diminta terlebih dahulu, namun ada juga yang dilakukan melalui permohonan permintaan dari pihak pengelola sumber belajar. Di sini berarti, kita harus aktif mencari berbagai informasi termasuk alamat lembaga atau institusi yang membuka peluang untuk memberikan bantuan.

Membuat sumber belajar dapat juga dilakukan melalui kegiatan perancangan dan pembuatan yang disiapkan secara khusus oleh guru untuk kegiatan pembelajaran tertentu. Dalam pembuatan sumber belajar untuk peserta didik, tergantung pada kreativitas dari guru itu sendiri, sehingga secara tidak langsung guru dituntut untuk dapat sekreatif mungkin dalam membuat sumber belajar, seperti membuat alat permainan edukatif dari bahan-bahan disekitar rumah yang mudah ditemui atau menata ruang kelas sedemikian mungkin, misalnya membuat hiasan-hiasan dengan berbagai bentuk, di dalam bentuk itu diberi huruf-huruf alphabet supaya anak dapat mengenal huruf dan bentuk-bentuk binatang ataupun bendabenda.

Memodifikasi yang tersedia,ada kalanya tidak sesuai dengan tujuan pendidikan yang hendak dicapai oleh karena itu perlu dilakukan modifikasi atau menyesuaikan dengan kebutuhan. Pemeliharaan sumber belajar guru harus mampu membedakan antara jenis sumber belajar yang perlu disimpan dan dipelihara dengan baik. Menyimpan sumber belajar 


\begin{tabular}{|l|l|r|}
\hline A1 Fitrah & Pengelolaan Sumber Belajar dalam \\
\hline Journal Of Early Childhood Islamic Education & Meningkatkan Pemahaman Peserta \\
didik \\
ISSN : 2599-2287 E-ISSN : 2622-335X \\
Vol.2 No.1 Juli 2018
\end{tabular}

berarti: merawat sumber belajar agar selalu relatif berada pada kondisi aslinya, memperbaiki kerusakan yang dialaminya dan menyimpannya dengan baik.

Berikut ini disajikan perawatan, perbaikan dan penyimpanan beberapa sumber belajar dan alat permainan: Koleksi gambar penting dipelihara apalagi gambar yang terbuat dari selembar kertas umumnya mudah robek dan sulit penyimpanannya.Pemeliharaan gambar dapat diupayakan dengan cara menempelkannya pada karton yang baik kualitasnya dan menyimpannya dengan baik. Pilihlah karton yang tidak mengandung bahan yang dapat merusak warna gambar. Jika tidak ada karton yang baik, lekatkan dulu kertas putih di atas karton selanjutnya gambar di atas kertas putih itu. Agar hasilnya baik, gunakan lem perekat yang baik kualitasnya agar kualitas gambar tidak cepat berubah oleh proses kimia yang ditimbulkan lem tersebut.

Cara menyimpan gambar adalah sebagai berikut: tiap gambar dicatat sesuai nomor urut disertai keterangan agar mudah mencari dan mengembalikannya ke tempat semula, sediakan rak-rak tempat menyimpan gambar dengan tiga macam ukuran gambar (besar, sedang, kecil) jumlah gambar yang disimpan dalam rak jangan terlalu banyak, umumnya dibatasi 20 lembar di setiap rak, penyimpanan diatur menurut besar kecilnya bukan isinya atau pesannya.Menyimpan menurut isinya bisa membingungkan dan gambar yang kecilkecil bisahilang atau terselip diantara gambar yang besar. Oleh karena itu tetapkan ukurannya (besar, sedang dan kecil) kemudian beri nomor urut dan gambar disimpan dengan meletakkannya secara mendatar (bukan dilipat atau digulung).

Alat Permainan Selain penyimpanan yang teratur terhadap alat-alat permainan, juga perlu di perhatikan mengenai pemeliharaan sumber belajar seperti tingkat kelembaban ruang udara pada sumber belajar. Tempat yang lembab dapat membuat sumber belajar berupa alat permainan edukatif menjamur, lapuk, kemudian mengelupas. Selain dapat membuat iritasi kulit pada tangan anak, alat permainan juga akan menjadi kusam dan warnanya pudar sehingga warnya tidak menarik bagi anak. Beberapa tempat yang aman digunakan untuk menyimpan berbagai alat permainan edukatif, antara lain rak dan lemari tertutup. Rak Alat-alat permainan yang di simpan dalam rak sebaiknya di berikan label nama alat permainan tersebut. Tujuannya selain membiasakan anak memperkenalkan bahasa tulis, mereka juga mengetahui nama 


\begin{tabular}{|l|l|r|}
\hline & Al Fitrah & Pengelolaan Sumber Belajar dalam \\
Journal Of Early Childhood Islamic Education & Meningkatkan Pemahaman Peserta \\
didik \\
ISSN : 2599-2287 E-ISSN : 2622-335X \\
Vol.2 No.1 Juli 2018
\end{tabular}

alat-alat permainan serta mendidik mereka untuk di siplin dalam mengambil dan mengembalikan alat-alat permainan yang ada dan lemari tertutup biasanya digunakan untuk menyimpan barang barang yang sangat rentan, misalnya yang terbuat dari kaca atau yang penggunaannya membutuhkan suatu pengawasan

\section{Penutup}

Berbagai sumber belajar yang dimanfaatkan dalam proses pembelajaran, seperti sumber belajar orang, metode, lingkungan dan informasi oleh guru dalam melaksanakan pembelajaran. Sumber belajar bahan merupakan sumber belajar yang sering dimanfaatkan, berupa: buku, makalah, papan, peta, globe, film, gambargambar, diagram, majalah, jurnal, dan surat kabar; sumber belajar latar, bentuk sumber belajar yang dimanfaatkan adalah perpustakaan, laboratorium, dan taman sekolah; sumber belajar teknik, bentuk sumber belajar yang dominan dimanfaatkan adalah ceramah, ceramah bervariasi, diskusi, pembelajaran terprogram, pembelajaran individual, pembelajaran kelompok, simulasi, permainan, studi eksplorasi, studi lapahgan, tanya jawab, dan pemberian tugas; Sedangkan sumber belajar alat yang dimanfaatkan adalah komputer,
LCD, OHP, kamera, radio, televisi, dan tape recorder.

Ada berbagai beberapa pola interaksi dalam pemanfaatan sumber belajar di lembaga pendidikan, seperti pola tradisional pasif, pola tradisional aktif, pola interaksi multi arah, dan pola interaksi mandiri. Pola tradisonal pasif adalah pola interaksi pemelajar dengan sumber belajar, di mana guru dijadikan sebagai satusatunya sumber belajar, tidak ada upaya tenaga pengajar mencari sumber belajar lain di luar dirinya. Pola tradisional aktif adalah pola interaksi tenaga pengajar dengan sumber belajar, di mana peserta didik menjadikan tenaga pengajar sebagai sumber belajar utama, memang sudah ada upaya untuk menemukan sumber belajar lain secara parsial untuk melengkapi pesanpesan yang diperoleh dari tenaga pengajar.

Pola interaksi berbagai arah ini, adalah pola interaksi antara peserta didik dengan berbagai sumber belajar dan dimana peserta didik menempatkan seluruh sumber belajar dalam posisi setingkat. Pola interaksi mandiri adalah pola interaksi peserta didik dengan sumber belajar di mana peserta didik aktif berinteraksi secara mandiri dengan sumber belajar tanpa kontrol dari tenaga pengajarnya. Ada kecenderungan pemanfaatan berbagai sumber belajar pada satuan pendidikan 


\begin{tabular}{|l|l|r|}
\hline A1 Fitrah & $\begin{array}{r}\text { Pengelolaan Sumber Belajar dalam } \\
\text { Meningkatkan Pemahaman Peserta } \\
\text { didik } \\
\text { Journal Of Early Childhood Islamic Education } \\
\text { ISSN : 2599-2287 E-ISSN : 2622-335X }\end{array}$ \\
Vol.2 No.1 Juli 2018 & Suhirman \\
\hline
\end{tabular}

dipengaruhi oleh dua faktor utama yaitu faktor internal dan faktor ekternal. Faktorfaktor internal yang berpengaruh dominan adalah kesadaran, semangat, minat, kemampuan, dan kenyamanan dalam diri pengguna. Sedangkan faktor-faktor eksternal yang berpengaruh adalah ketersediaan sumber belajar yang bervariasi, sumber belajar kuantitas, kemudahan akses terhadap sumber belajar, proses pembelajaran, ruang, sumber daya manusia, serta tradisi dan sistem yang sedang berlaku di sekolag/ lembaga pendidkkan.

Pendidik dan peserta didik pada satuan pendidikan memandang bahwa ketersediaan sumber belajar di satuan pendidikan tertentu masih sangat terbatas. Keterbatasan tersebut dirasakan pada beberapa aspek seperti aspek kualitas dan kuatitas sumber belajar, aspek variasi sumber belajar, aspek kemudahan akses terhadap sumber belajar, aspek bentuk dan jenis sumber belajar yang benar-benar tersedia.

\section{Daftar Pustaka}

Deni, Darmawan, 2012, Pendidikan Teknologi Informasi dan Komunikasi, Bandung: PT. Remaja Rosdakarya

Davies, K, 1986, Pengelolaan Belajar, Jakarta: CV Rajawali
Miarso, Yusufhadi. 2004. Menyemai benih teknologi pendidikan. Jakarta: Kencana.

Rusli, 2009. Teknologi Komunikasi dan Informasi dalam Pendidikan: Kurikulum untuk Sekolah dan Program Pengembangan Guru ,Jakarta: Gaung Persada. 